\title{
Ecological characterization and molecular differentiation of Culex pipiens complex taxa and Culex torrentium in eastern Austria
}

\author{
Carina Zittra ${ }^{1 \dagger}$, Eva Flechl ${ }^{1 \dagger}$, Michael Kothmayer ${ }^{1}$, Simon Vitecek² ${ }^{2}$ Heidemarie Rossiter ${ }^{3}$, Thomas Zechmeister $^{4}$ \\ and Hans-Peter Fuehrer ${ }^{1 *}$
}

\begin{abstract}
Background: Culex pipiens complex taxa differ in behaviour, ecophysiology and epidemiologic importance. Despite their epidemiologic significance, information on genetic diversity, occurrence and seasonal and spatial distribution patterns of the $C x$. pipiens complex is still insufficient. Assessment of seasonal and spatial distribution patterns of Culex pipiens forms and their congener $C x$. torrentium is crucial for the understanding of their vector-pathogen dynamics.

Methods: Female mosquitoes were trapped from April-October 2014 twice a month for a 24-h time period with BG-sentinel traps at 24 sampling sites in eastern Austria, using carbon dioxide as attractant. Ecological forms of CX. pipiens s.l. and their hybrids were differentiated using the CQ11 locus, and CX. pipiens forms and their congener $C x$. torrentium using the ACE-2 gene. Differential exploitation of ecological niches by $C x$. pipiens forms and $C x$. torrentium was analysed using likelihood ratio tests. Possible effects of environmental parameters on these taxa were tested using PERMANOVA based on distance matrices and, if significant, were modelled in nMDS ordination space to estimate non-linear relationships.

Results: For this study, 1476 Culex spp. were sampled. Culex pipiens f. pipiens representing $87.33 \%$ of the total catch was most abundant, followed by hybrids of both forms (5.62 \%), Cx. torrentium (3.79\%) and CX. pipiens f. molestus (3.25\%). Differences in proportional abundances were found between land cover classes. Ecological parameters affecting seasonal and spatial distribution of these taxa in eastern Austria are precipitation duration, air temperature, sunlight and the interaction term of precipitation amount and the Danube water level, which can be interpreted as a proxy for breeding habitat availability.

Conclusions: The Cx. pipiens complex of eastern Austria comprises both ecologically different forms, the mainly ornithophilic form pipiens and the mainly mammalophilic and anthropophilic form molestus. Heterogeneous agricultural areas as areas of coexistence may serve as hybridization zones, resulting in potential bridge vectors between birds and humans. Occurrence, seasonal and spatial distribution patterns of the $C x$. pipiens complex and $C x$. torrentium and the presence of hybrids between both forms were quantified for the first time in Austria. These findings will improve the knowledge of their vector-pathogen dynamics in this country.
\end{abstract}

Keywords: Mosquito, Vector, Diversity, Autecology, CQ11, Acetylcholinesterase (ACE gene)

\footnotetext{
* Correspondence: hans-peter.fuehrer@vetmeduni.ac.at

${ }^{\dagger}$ Equal contributors

${ }^{1}$ Department of Pathobiology, Institute of Parasitology, University of

Veterinary Medicine Vienna, Vienna, Austria

Full list of author information is available at the end of the article
} 


\section{Background}

Species of the Culex (Culex) pipiens complex are hardly distinguishable due to their morphological similarity, but differ extensively in behaviour, physiology and host preference. The complex is considered to consist of seven taxa: $C x$. quinquefasciatus Say, $C x$. pipiens pallens Coquillet, $C x$. australicus Dobrotworsky \& Drummond, Cx. globocoxitus Dobrotworsky and the nominal species, $C x$. pipiens L., comprising two genetically and ecologically distinct forms: Culex pipiens f. pipiens, which is repeatedly described and examined as ornithophilic, diapausing, anautogenous, and eurygamous, whereas Culex pipiens f. molestus is interpreted as mammophilic (and especially anthropophilic), autogenous, and stenogamous [1-4]. Both forms are known to hybridize in areas of coexistence $[5,6]$, potentially resulting in bridge vector populations presumed to feed mostly on birds, but also on humans [4]. However, hybridization events in central and northern Europe potentially are rare due to selective and exclusive habitat use of both forms [7-11]. Genetically distinct non-members, but often indistinguishable species from those in the $C x$. pipiens complex are $C x$. torrentium Martini in northern Europe, $C x$. restuans Theob., Cx. nigripalpus Theob. and $C x$. salinarius Coquillet in North America, Cx. pervigilans Von Bergroth in New Zealand and $C x$. vagans Wiedemann in central and eastern Asia [12].

Culex pipiens complex taxa are key vectors succouring the transmission of a variety of pathogens such as avian malaria (Plasmodium spp.) and filarioid helminths (Dirofilaria spp.) $[13,14]$ and are considered to be main vectors of West Nile virus [15-18] and highly competent vectors for Usutu virus [19]. The presumed ornithophilic $C x$. pipiens f. pipiens and $C x$. torrentium are additionally vectors of Sindbis virus and differ in vector competence. Different transmission efficiencies for Sindbis virus (the causative agent of Ockelbo disease and Karelian fever $[20,21])$ were found in $C x$. torrentium and $C x$. pipiens $\mathrm{f}$. pipiens by transmission experiments in which the former species was found to be a more efficient vector [22]. Sindbis virus seroprevalence linked to migratory bird infection rates was found to fluctuate in the human population in northern Europe [23], and recently the Sindbis virus was isolated in Germany from $C x$. torrentium [24]. Furthermore, $C x$. torrentium is under discussion as a potentially better vector of West Nile virus than $C x$. pipiens $\mathrm{f}$. pipiens [25]. In addition, $C x$. pipiens $\mathrm{f}$. molestus was identified as vector of West Nile virus with the potential for vertical transmission within local populations [26]. Precise data on the distribution and ecology of these taxa are necessary to assess potential risks for local human populations [23] and biodiversity (e.g. [27]). The absence of stable morphological determination characters and sympatric occurrence in some Culex species however resulted in incomplete or erroneous data on spatial and seasonal distribution of these taxa [28]. This clearly necessitates detailed scrutinization of the ecology of Culex species, including $C x$. pipiens complex taxa. However, only males or larvae of $C x$. pipiens forms and $C x$. torrentium can be distinguished reliably (by either the structure of the phallosome on the hypopygium [29, 30] or chaetotaxy [31]), but neither males nor larvae are of major interest in strictly epidemiological studies.

Species identification of morphologically hardly separable females of Culex spp. is nonetheless feasible by means of molecular methods. The mitochondrial cytochrome oxidase $c$ subunit I can be used to distinguish $C x$. torrentium from $C x$. pipiens complex taxa [32], but attempts to identify hybrids between these taxa based on a length variation in the di-nucleotid microsatellite locus CQ11 potentially lead to some molecular misidentification of $C x$. torrentium and $C x$. pipiens forms [33]. Even so, utilization of two different protocols $[1,34]$ enables indisputable identification of $C x$. pipiens f. pipiens, Cx. pipiens f. molestus, and their hybrids, Cx. torrentium. To our knowledge this is the first study to quantitatively examine the seasonal and spatial distribution patterns of the Culex pipiens forms and their sister taxon Cx. torrentium in Austria. This knowledge is crucial for the understanding of vector-pathogen dynamics in Austria and is furthermore essential for the implementation of appropriate mosquito surveillance and control strategies.

\section{Methods}

\section{Mosquito sampling and identification}

In our study 24 permanent sampling sites distributed across Lower Austria, of which two were located in Vienna (only on artificial surfaces), 14 in Lower Austria (representing predominantly artificial surfaces) and eight in Burgenland (representing predominantly agricultural areas), were monitored from April to October 2014. Mosquito communities including members of the Culex pipiens complex were sampled every second week for a 24-h time period using mosquito traps (Biogents ${ }^{\circ}$, Regensburg, Germany) baited with carbon dioxide as an attractant and were stored at $-80{ }^{\circ} \mathrm{C}$. Female mosquitoes were identified by morphological determination characters using the key of Becker et al. [31]. Identification of morphologically cryptic mosquito females of the $C x$. pipiens complex and $C x$. torrentium was performed following Smith \& Fonseca [34] (exploiting an intron length polymorphism in the ace-2 gene to differentiate Cx. torrentium from Cx. pipiens forms) and Bahnck \& Fonseca [1] (exploiting a length polymorphism of the CQ11 gene to distinguish $C x$. pipiens $\mathrm{f}$. pipiens and $C x$. pipiens f. molestus). 


\section{Molecular analysis}

Whole genomic DNA was extracted from three legs or the head capsule of each single specimen separately using the DNeasy Blood \& Tissue Kit (Qiagen, Hilden, Germany) according to the manufacturer's protocol. To differentiate $C x$. pipiens forms from $C x$. torrentium partial amplification of ace-2 (cf. [34]) was performed using primers ACEpip, ACEpall, ACEtorr and B1246s in standard PCR protocols and cycling conditions $(1 \mu \mathrm{l}$ DNA, $5 \times$ Green Taq $^{\bullet}$ Reaction Buffer, 10 pMol of each primer, $0.2 \mathrm{mMol}$ of each dNTP, $1 \mathrm{U}$ Taq Polymerase (Promega), dd $\mathrm{H}_{2} \mathrm{O}$ to $20 \mu \mathrm{l} ; 5 \mathrm{~min}$ at $95{ }^{\circ} \mathrm{C}, 35 \times(30 \mathrm{~s}$ at $55^{\circ} \mathrm{C}, 1 \mathrm{~min}$ at $72{ }^{\circ} \mathrm{C}, 30 \mathrm{~s}$ at $\left.94{ }^{\circ} \mathrm{C}\right), 5 \mathrm{~min}$ at $\left.72{ }^{\circ} \mathrm{C}\right)$. PCR products were separated using gel electrophoresis targeting 634 bp (Cx. pipiens forms) and 512 bp (Cx. torrentium) DNA fragments. Differentiation of $C x$. pipiens f. pipiens and $C x$. pipiens f. molestus based on partial CQ11 sequences ( $c f$. [1]) was performed using primers CQ11F2, pip CQ11R and mol CQ11R in standard PCR protocols and cycling conditions $(1 \mu \mathrm{l}$ DNA, $5 \times$ Green Taq ${ }^{\oplus}$ Reaction Buffer, $10 \mathrm{pMol}$ of each primer, $2.5 \mathrm{mM}$ $\mathrm{MgCl}_{2}, 0.2 \mathrm{mM}$ of each dNTP, $1 \mathrm{U}$ Taq Polymerase (Promega), $\mathrm{ddH}_{2} \mathrm{O}$ to $25 \mu \mathrm{l} ; 5 \mathrm{~min}$ at $95^{\circ} \mathrm{C}, 40 \times\left(30 \mathrm{~s}\right.$ at $54{ }^{\circ} \mathrm{C}$, $40 \mathrm{~s}$ at $72{ }^{\circ} \mathrm{C}, 30 \mathrm{~s}$ at $\left.95^{\circ} \mathrm{C}\right), 5 \mathrm{~min}$ at $72^{\circ} \mathrm{C}$ ). PCR products were visualized using gel electrophoresis targeting $185 \mathrm{bp}$ (Cx. pipiens $\mathrm{f}$. pipiens) and $241 \mathrm{bp}$ (Cx. pipiens $\mathrm{f}$. molestus) DNA fragments. Further, ACE-2 and CQ11 fragments of several hybrids, $C x$. pipiens f. molestus, $C x$. pipiens $\mathrm{f}$. pipiens were purified and directly sequenced by a commercial company (LGC Genomics, Germany) to confirm results from electrophoresis (data not shown).

Additionally, partial amplification of approximately 700 bp fragments of mitochondrial cytochrome $c$ oxidase subunit I (COI) was performed using primers $\mathrm{H} 15 \mathrm{Culi}$ COIFw and H15CuliCOIRv (Table 1) in standard protocols and cycling conditions $\left(1 \mu\right.$ l DNA, $5 \times$ Green Taq $^{\odot}$ Reaction Buffer, $20 \mathrm{pMol}$ of each primer, $0.2 \mathrm{mM}$ of each dNTP, $1 \mathrm{U}$ Taq Polymerase (Promega), $\mathrm{ddH}_{2} \mathrm{O}$ to $25 \mu \mathrm{l}$; $2 \mathrm{~min}$ at $95{ }^{\circ} \mathrm{C}, 35 \times\left(1 \mathrm{~min}\right.$ at $95{ }^{\circ} \mathrm{C}, 1 \mathrm{~min}$ at $50{ }^{\circ} \mathrm{C}$, $1 \mathrm{~min}$ at $72{ }^{\circ} \mathrm{C}$ ), $10 \mathrm{~min}$ at $72{ }^{\circ} \mathrm{C}$ ) of five individuals of each taxon to ensure adequate differentiation of $C x$. torrentium and $C x$. pipiens forms as internal quality control (GenBank Accession numbers KU756484-KU756487).

\section{Habitat preferences}

Proportional differences in abundance of Culex taxa in eastern provinces of Austria (corrected against number of sampling sites per province) were assessed using a
Williams-corrected likelihood ratio test (G-test) of independence [35]. Additionally, sampling sites were assigned to specific habitat types using the CORINE [Co-ordinated Information on the Environment] Land Cover [36] database to investigate potential habitat type preferences of Culex taxa. CLC was selected because of its high spatial resolution $(1: 100,000)$ and the methodological homogeneity used for the land cover classification. To detect differences in the abundance of Culex spp. in land cover classes a Williams-corrected likelihood ratio test (G-test) of goodness of fit was used.

Seasonal and spatial variations in Culex spp. communities Differential abundance of $C x$. pipiens complex taxa per month and province was assessed using linearized graphical representations of Bray-Curtis distances produced by means of non-metric multidimensional scaling (nMDS). Meteorological data, such as temperature, air pressure, humidity, amount and duration of precipitation of 15 weather stations distributed across the sampling area were provided by the Austrian Central Institute for Meteorology and Geodynamics (ZAMG). These parameters, together with water levels of the aquatic habitats, primarily influence egg-laying, larval development and availability of larval habitats [37, 38]. Thus, 14-day means prior to the sampling date were computed to account for effects of meteorological parameters on abundance and occurrence of sampled Culex taxa. Effects of meteorological parameters were assessed using permutational multivariate analysis of variance (PERMANOVA) on dissimilarity matrices as implemented in the 'vegan' package [39], based on raw mosquito data pooled per month and province. Parameters contributing significantly to the observed patterns were subsequently modelled in ordination space using the function "ordisurf()" to estimate non-linear relationships. Species abundance in relation to communities was assessed by computing and plotting weighted average species scores. All statistical analyses were performed in the $\mathrm{R}$ statistical environment ( $\mathrm{R}$ Development Core Team, 2011).

\section{Results \\ Mosquito sampling}

For this study 1476 Culex spp. were sampled. Cx. pipiens $\mathrm{f}$. pipiens represented with $87.33 \%$ of the total catch $(n=1289)$ the most abundant species in all provinces, followed by hybrids between $C x$. pipiens f. pipiens and $C x$. pipiens f. molestus $(5.62 \%, n=83), C x$. torrentium

Table 1 Diptera-specific PCR primers designed in this study

\begin{tabular}{llll}
\hline Specifity & Genetic marker & Primer & Sequences of primer (5'-3') \\
\hline Diptera & COI & H15CuliCOIFw & AGCCATTTAATCGCGACAA \\
& & H15CuliCOIRv & GGATGTCCAAAAAATCAAAATAAATGTT \\
\hline
\end{tabular}


(3.79\%, $n=56)$ and Cx. pipiens f. molestus (3.25\%, $n=$ 48). In Vienna 244 individuals of $C x$. pipiens $\mathrm{f}$. pipiens, 28 $C x$. torrentium, 25 hybrids and $13 C x$. pipiens $\mathrm{f}$. molestus were collected. In Lower Austria $C x$. pipiens f. pipiens was highly abundant with 612 individuals sampled, along with a further 25 hybrids, $21 C x$. torrentium and $17 C x$. pipiens f. molestus were collected in this province. In Burgenland 433 Cx. pipiens f. pipiens, 33 hybrids, $18 C x$. pipiens $\mathrm{f}$. molestus and seven $C x$. torrentium were identified. Sympatric occurrence of $C x$. pipiens $\mathrm{f}$. pipiens and $C x$. torrentium was observed at 14 sampling locations. Sympatric occurrence of both ecological forms of $C x$. pipiens was observed at 11 sampling localities.

\section{Habitat preferences}

Proportional abundances of $C x$. pipiens f. pipiens $(\mathrm{G}=$ 4.1799, X-squared $\mathrm{df}=2, P=0.1237), C x$. pipiens $\mathrm{f}$. molestus ( $\mathrm{G}=0.26319$, $\mathrm{X}$-squared $\mathrm{df}=2, P=0.8767$ ), hybrids $(\mathrm{G}=0.71983, \mathrm{X}$-squared $\mathrm{df}=2, P=0.6977$ ) and $C x$. torrentium did not differ significantly between the provinces $(\mathrm{G}=1.3399, \mathrm{X}$-squared $\mathrm{df}=2, P=0.5117)$.

Based on an analysis of differential distribution of Culex spp. in habitat types of CORINE Land Cover Level 1 habitat types, $C x$. pipiens forms occur predominately in agricultural areas and $C x$. torrentium on artificial surfaces. Significant differences in proportional abundances were found exclusively for $C x$. pipiens $\mathrm{f}$. pipiens in CLC level 2 habitat types (highest abundances in arable land; $\mathrm{G}=13.312$, $\mathrm{X}$-squared $\mathrm{df}=5, P=0.02062$ ) and in CLC level 3 habitat types (highest abundances in nonirrigated arable land; $\mathrm{G}=19.766, \mathrm{X}$-squared $\mathrm{df}=7, P=$ 0.006098). The other taxa examined did not differ significantly in their proportional abundances. Highest abundances of $C x$. pipiens f. pipiens were recorded in complex cultivation patterns and non-irrigated arable land (CLC level 3), whereas Cx. pipiens f. molestus was most abundant in complex cultivation patterns (CLC level 3). Hybrids of $C x$. pipiens $\mathrm{f}$. pipiens and $C x$. pipiens f. molestus were most abundant in non-irrigated arable land (CLC level 3) and Cx. torrentium in discontinuous urban fabric regions (CLC level 3).

\section{Seasonal and spatial variations in Culex pipiens complex communities}

PERMANOVA indicated effects of some meteorological parameters on spatial and seasonal variations of Culex spp.: air temperature, sunshine duration and the amount of precipitation are possible drivers of the seasonal and spatial differentiation. Further, the interaction term of amount of precipitation and Danube water level, a proxy of breeding habitat availability, was found to structure communities (Table 2).

Culex pipiens complex communities differed from one another in relation to sampling province and time.
Viennese, Burgenland and Lower Austrian samples were depicted with a large spread, indicating differentiated communities throughout the sampling period (Figs. 1, 2). Viennese June and August, Lower Austrian June, July, August and September, and Burgenland August, September and October communities were loosely arranged around average weighted species scores. Communities characterized by low abundances (Viennese April, May and September, and Lower Austrian April) were more similar to one another and to all other communities sampled. May communities sampled in Burgenland and Lower Austria were relatively similar to one another and to Viennese July communities. Viennese September and Burgenland June communities were somewhat separate from the rest.

Generalized additive modelling of environmental parameters identified by PERMANOVA as potential drivers of community composition (Table 2) in ordination space suggests high abundances of all taxa to be associated with high air temperatures (Fig. 1), intermediate sunshine duration per day (Fig. 2), high duration of precipitation, and combined high Danube water levels and amounts of precipitation.

\section{Discussion}

Taxonomy, abundance and habitat preference of $C x$. pipiens forms and $C_{x}$. torrentium in eastern Austria

Our results indicate that all taxa of the $C x$. pipiens complex are common and widely distributed in eastern Austria. Additionally, sympatric co-occurrence of $C x$. torrentium and $C x$. pipiens $\mathrm{f}$. pipiens was observed at 14 sampling localities throughout eastern Austria, predominately in discontinuous urban fabric habitats (CLC level 3 ). While formerly considered a rare species [40], recent surveys in Germany suggest $C x$. torrentium to be one of the most abundant mosquitoes in Europe [41]. Previous under-representation of this species is potentially linked to cryptic taxonomic characters thwarting morphological identification (cf. [40, 41]). Distribution of adult $C x$. pipiens f. pipiens and $C x$. torrentium assessed in the present study suggests shared habitats, confirming prior studies on co-occurrence of larvae in a variety of breeding habitats (e.g. [3, 30, 41-46]). Further, the distribution of $C x$. torrentium suggests a preference for discontinuous urban fabric, corroborating a preference for anthropogenic habitats (e.g. [25, 30, 47]).

Sympatric co-occurrence of $C x$. pipiens forms was observed in 11 out of 24 sampling localities in Lower Austria. Culex pipiens forms were most abundant in agricultural areas, especially arable land and heterogeneous agricultural areas (CLC level 2), where $C x$. pipiens f. pipiens and $C x$. pipiens $\mathrm{f}$. molestus are associated with complex cultivation patterns in co-occurrence, and $C x$. pipiens $\mathrm{f}$. pipiens and hybrids predominately co-occur in 
Table 2 Environmental parameters tested using PERMANOVA based on distance matrices (adonis(): 'vegan' package, Oksanen et al. [39])

\begin{tabular}{|c|c|c|c|c|c|c|}
\hline Ecological parameter & Df & SumsOfSqs & MeanSqs & F.Model & $\mathrm{R} 2$ & $\operatorname{Pr}(>\mathrm{F})$ \\
\hline Humidity & 1 & 0.2248 & 0.22478 & 41.529 & 0.06851 & 0.066 \\
\hline Precipitation duration & 1 & 0.3366 & 0.33657 & 62.182 & 0.10258 & $0.023^{*}$ \\
\hline Amount of precipitation & 1 & 0.1949 & 0.19489 & 36.007 & 0.05940 & 0.078 \\
\hline Air temperature & 1 & 0.5645 & 0.56455 & 104.302 & 0.17207 & $0.007^{* *}$ \\
\hline Sunlight duration & 1 & 0.4238 & 0.42382 & 78.301 & 0.12917 & $0.009^{* *}$ \\
\hline Deciduous forest cover & 1 & 0.1795 & 0.17945 & 33.154 & 0.05469 & 0.094 \\
\hline Green urban areas & 1 & 0.1080 & 0.10797 & 19.949 & 0.03291 & 0.187 \\
\hline Danube water level & 1 & 0.0325 & 0.03252 & 0.6008 & 0.00991 & 0.576 \\
\hline Humidity:Danube water level & 1 & 0.0839 & 0.08393 & 15.506 & 0.02558 & 0.268 \\
\hline Precipitation duration:Danube waterlevel & 1 & 0.0662 & 0.06617 & 12.225 & 0.02017 & 0.318 \\
\hline Amount of precipitation:Danube water level & 1 & 0.4038 & 0.40379 & 74.601 & 0.12307 & $0.020^{*}$ \\
\hline Air temperature:Danube water levl & 1 & 0.1570 & 0.15703 & 29.011 & 0.04786 & 0.102 \\
\hline Sunshine duration:Danube water level & 1 & 0.1186 & 0.11865 & 21.920 & 0.03616 & 0.156 \\
\hline Deciduous forest cover:Danube water level & 1 & 0.1394 & 0.13938 & 25.751 & 0.04248 & 0.135 \\
\hline Green urban areas:Danube water level & 1 & 0.0310 & 0.03097 & 0.5722 & 0.00944 & 0.588 \\
\hline Residuals & 4 & 0.2165 & 0.05413 & & 0.06599 & \\
\hline Total & 19 & 32.810 & & & 100.000 & \\
\hline
\end{tabular}

Asterisks indicate significant effects of certain environmental parameters $\left({ }^{*}, P \leq 0.05 ;{ }^{* *}, P \leq 0.01\right)$

non-irrigated arable land (CLC level 3). Furthermore, a high proportion of hybrids in these habitat types, particularly non-irrigated arable land, characterizes them as hybridization zones. While a certain rate of hybridization of $C x$. pipiens $\mathrm{f}$. pipiens and $C x$. pipiens $\mathrm{f}$. molestus is common, these forms supposedly occur in distinct habitats types linked to their ecological peculiarities: whereas $C x$. pipiens $\mathrm{f}$. pipiens is reported to be ubiquitous, $C x$. pipiens $\mathrm{f}$. molestus is described as restricted to so-called (mostly anthropogenic) 'underground' habitats (e.g. in Morocco [48], Spain [7], Portugal [49] and Netherlands [5]). Also, the occurrence of $C x$. pipiens f. molestus and co-occurrence of $C x$. pipiens forms was observed in Germany and Portugal in

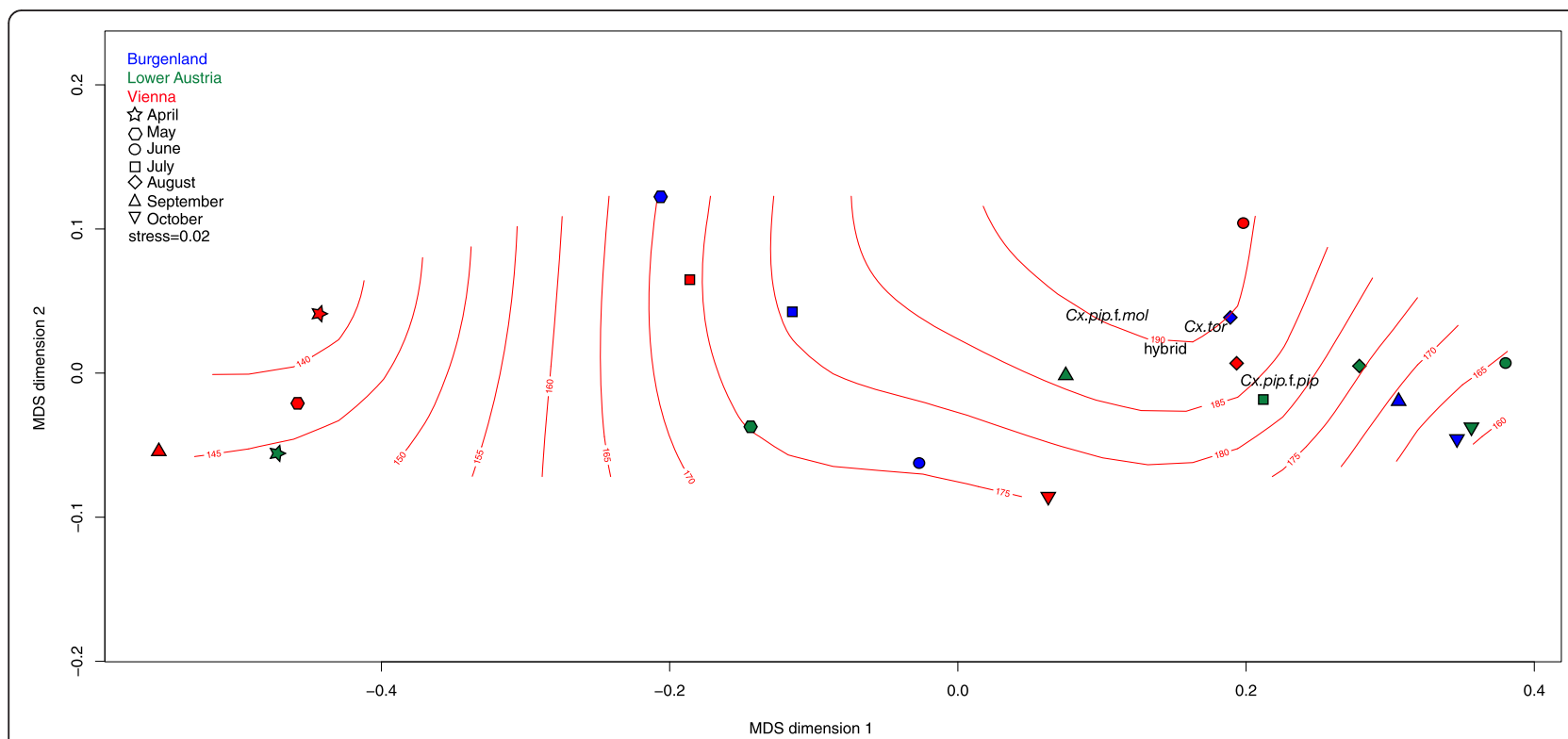

Fig. 1 Configuration of spatial and temporal fluctuations of Culex spp. communities in eastern Austria in a two dimensional NMDS representation of Bray-Curtis distances. Isolines represent air temperature $\left[{ }^{\circ} \mathrm{C} \times 10^{-1}\right]$ variability throughout the sampling period modelled in ordination space using a generalized additive modelling approach as implemented in ordisurf(), deviance in ordination space explained $=44.9 \%$; ${ }^{2}=<0.01$ 


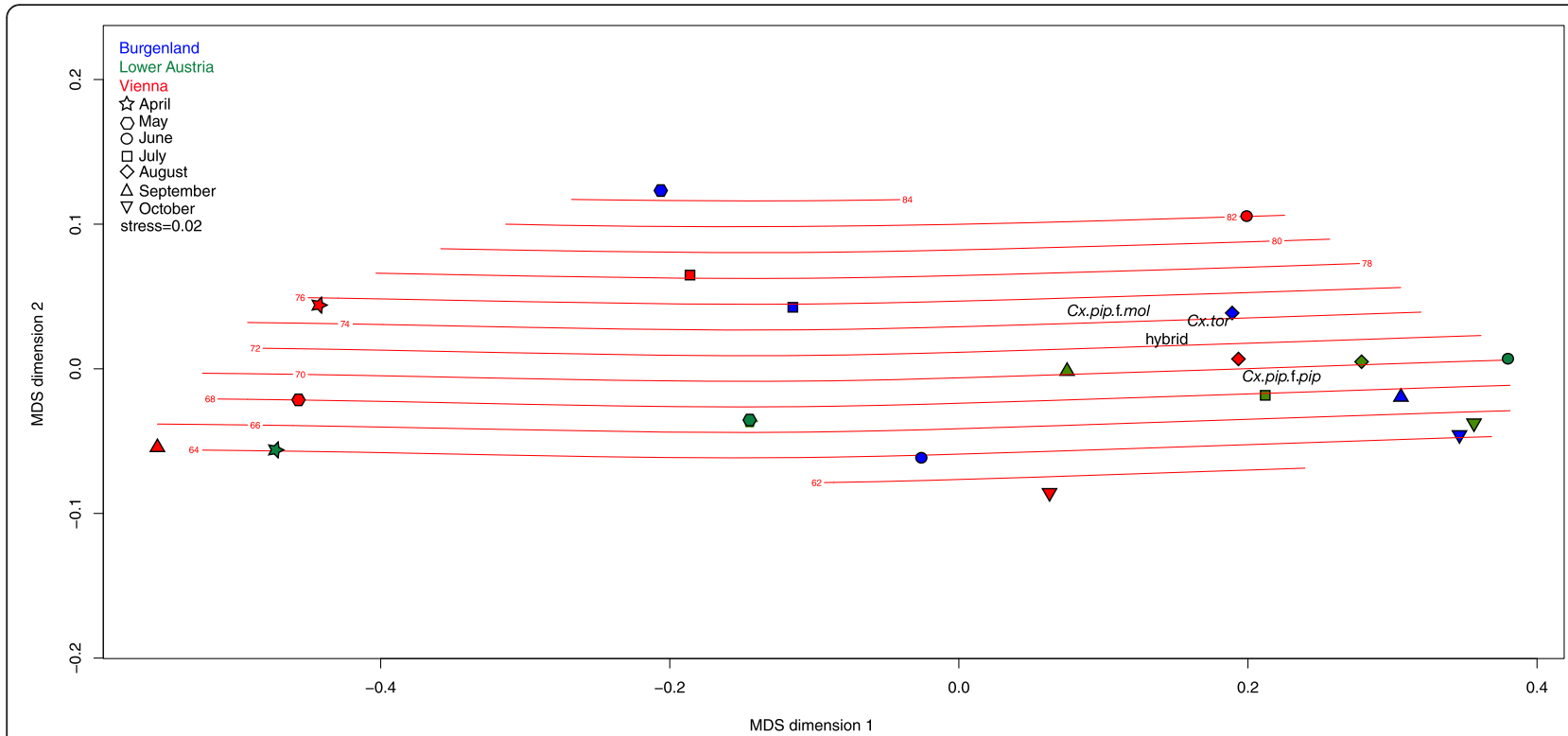

Fig. 2 Configuration of spatial and temporal fluctuations of Culex spp. communities in eastern Austria in a two dimensional NMDS representation of Bray-Curtis distances. Isolines represent sunshine duration variability throughout the sampling period modelled in ordination space using a generalized additive modelling approach as implemented in ordisurf(), deviance in ordination space explained $=25.7 \% ; R^{2}=<0.01$

highly urbanized areas $[3,4]$. Distribution patterns of Cx. pipiens f. pipiens and Cx. pipiens f. molestus recovered in this study contrarily indicate an association of both Cx. pipiens f. pipiens, Cx. pipiens f. molestus and their hybrids with arable land and agricultural areas. This is particularly noteworthy, as an increased potential for hybridization and the formation of bridge-vectors for West Nile virus or other mosquito-borne pathogens can be expected under such circumstances. Additionally, these results clearly necessitate intensified, focused investigations on habitat preference and the distribution of $C x$. pipiens complex taxa throughout Europe.

\section{Spatial and temporal variation of Culex taxa}

Temporal variation (as pattern of Bray-Curtis distances recovered by nMDS) of $C x$. pipiens complex taxa was observed throughout the sampling period with the most similar communities and highest abundances observed in the summer months. Meteorological parameters found to structure abundance and occurrence mostly affect developmental time and abundance (via larval survival and larval habitat availability) generation cycles (cf. $[38,50])$. Furthermore, Cx. pipiens f. pipiens occurred earlier in the year than $C x$. torrentium and $C x$. pipiens $\mathrm{f}$. molestus. This suggests somewhat higher temperature optima of these latter taxa and additionally supports the hypothesis of a more southern distribution and genesis of $C x$. pipiens $\mathrm{f}$. molestus $[15,51,52]$ and $C x$. torrentium [41]. However, the latter species is reported as widely absent in the Mediterranean region [41]. Putatively, this supposedly strict ornithophilic taxon is more strongly affected by other environmental parameters that also control abundance of its preferred host, e.g. habitat heterogeneity. However, the interpretability of results presented in this work is limited by the low number of specimens collected, a problem encountered by several other studies which focussed on adults (cf. [25, 53]). Nevertheless, these results indicate that a wide range of suitable larval habitats is present in eastern Austria, and, considering the low effectiveness of carbon-dioxide baited traps on certain culicid taxa, a large population of potential vectors for mosquito-borne pathogens must exist.

\section{Comments on efficacy of trapping methods}

Interestingly, a small proportion of all collected specimens were identified as $C x$. torrentium in our study. Under-representation of $C x$. torrentium in carbon dioxide baited traps is commonly observed (e.g. [41, 54]), and potentially leads to an under-estimation of the proportional abundance of $C x$. torrentium. This is particularly noteworthy, as carbon dioxide baited traps are described as attracting and catching a broad range of different mosquito species compared to other commonly used traps [55]. Differential efficacy of carbon dioxide baited traps was related to a relatively lower attractiveness of carbon dioxide to strictly ornithophilic species in comparison to anthropophilic or mammalophilic species [31, 41]. However, the supposedly mammalophilic and anthropophilic Cx. pipiens f. molestus (e.g. [31]) should consequently have been collected in higher numbers. While a large number of studies suggest strong 
attraction of culicidas to pure $\mathrm{CO}_{2}$ (e.g. [56, 57]), attractiveness of host odours seems to be controlled by prior sensitization through brief $\mathrm{CO}_{2}$ exposure in Ae. aegypti [58]. In addition, flight velocity, orientation of flight and source finding was found to increase post- $\mathrm{CO}_{2}$ exposure compared to naive specimens [58]. Potentially, $\mathrm{CO}_{2}$ acts rather as primary attractant and mediator eliciting higher sensitivity and thus the more specific response to host-odours [58]. Thus, the efficacy of carbon-dioxidebaited traps may be reduced in taxa requiring further cues to locate potent hosts. In particular, volatile substances from, for example, preen glands of birds ( $c f$. $[59,60])$ or serous glands of amphibia $(c f .[61,62])$ might be more important for host localization in ornithophilic or herpetophilic taxa such as $C x$. torrentium or Culiseta longiareolata [31]. Furthermore, additional host localization cues currently not considered (e.g. thermic signatures, $\mathrm{CO}_{2}$ concentration, optical cues) could be relevant for differential trap efficacy.

As sympatric occurrence with roughly equal abundances of $C x$. torrentium and $C x$. pipiens complex taxa is mainly demonstrated in larval surveys $[3,30,46]$, reliable estimates of abundance of $C x$. pipiens forms requires the analysis of larval community composition and exposition of gravid traps and ovitraps ( $c f$. [41]). Putatively, such surveys will also improve data on Cx. pipiens f. molestus distribution and habitat preference as this taxon is currently potentially under-represented in the majority of studies, similar to $C x$. torrentium.

\section{Conclusions}

In eastern Austria both ecological forms of Culex pipiens exist, the mainly ornithophilic form pipiens and the mainly mammalophilic and anthropophilic form molestus. $C x$. pipiens form pipiens is predominant in eastern Austria. Areas of co-occurrence are agricultural, peri-urban regions that may serve as areas of hybridization, resulting in bridge vectors between birds and humans. An assessment of occurrence, as well as seasonal and spatial distribution patterns of the $C x$. pipiens forms and $C x$. torrentium as well as the identification of hybrids was attained for the first time in Austria. These findings will contribute to the understanding of their vector-pathogen dynamics in this country.

\section{Competing interests}

The authors declare that they have no competing interests.

\section{Authors' contributions}

CZ and HPF took part in study design. CZ performed mosquito sampling, morphological mosquito identification and sample preparation, and compiled results and figures and drafted the manuscript. HR performed mosquito sampling. EF and MK performed molecular biological work (sample preparation, DNA extraction and PCRs), HPF performed sequence alignment. CZ and SV carried out statistical analysis on mosquito distribution and ecological data. TZ realized the mosquito sampling in Burgenland. HPF coordinated the research project, supervised molecular biological work and edited draft versions of the manuscript. All authors read, edited and approved the final manuscript.

\section{Acknowledgments}

This contribution is dedicated to the memory of Dr. Dieter Armerding (1941-2015).

The authors thank the National Park Donau-Auen GmbH, the WWF Auenreservat Marchegg and Storchenhaus Marchegg as well as the provincial government of Burgenland for their strong support in capturing the mosquitoes, as well as Stefan Weiss and others of the "Austrian League of Nature Conservation Burgenland" for their help organizing the mosquito sampling in specific areas. We are grateful to all citizen scientists who devotedly supported this project. We are thankful to Josef Harl for primer design (COI). We thank Dina Fonseca for helpful discussion. This research was funded by the ERA-Net BiodivERsA, with the national funders FWF I-1437, ANR-13-EBID-0007-01 and DFG BiodivERsA KL 2087/6-1 as part of the 2012-13 BiodivERsA call for research proposals. SV acknowledges support from the FWF (project number P23687-B17).

\section{Author details}

'Department of Pathobiology, Institute of Parasitology, University of Veterinary Medicine Vienna, Vienna, Austria. ${ }^{2}$ Department of Limnology and Bio-Oceanography, University of Vienna, Vienna, Austria. ${ }^{3}$ Donaustraße 73, 3421 Höflein/Donau, Austria. ${ }^{4}$ Biological Station Lake Neusiedl, Illmitz, Burgenland, Austria.

Received: 24 February 2016 Accepted: 5 April 2016

Published online: 11 April 2016

\section{References}

1. Bahnck CM, Fonseca DM. Rapid assay to identify the two genetic forms of Culex (Culex) pipiens L. (Diptera: Culicidae) and hybrid populations. Am J Trop Med Hyg. 2006;75:251-5.

2. Becker $\mathrm{N}$, Jöst A, Weitzel T. The Culex pipiens complex in Europe. J Am Mosq Control Assoc. 2012;28(4s):53-67.

3. Rudolf M, Czajka C, Börstler J, Melaun C, Jöst H, von Thien H, Badusche M, Becker N, Schmidt-Chanasit J, Krüger A, Tannich E, Becker S. First nationwide surveillance of Culex pipiens complex and Culex torrentium mosquitoes demonstrated the presence of Culex pipiens biotype pipiens/molestus hybrids in Germany. PLoS One. 2013;8(9):e71832.

4. Osório HC, Zé-Zé F, Amaro F, Nunes A, Alves MJ. Sympatric occurrences of Culex pipiens (Diptera: Culicidae) biotypes pipiens, molestus and their hybrids in Portugal, Western Europe: feeding patterns and habitat determinants. Med Vet Entomol. 2014;28:103-9.

5. Reusken CBEM, de Vries A, Buijs J, Braks MAH, den Hartog W, Scholte EJ. First evidence for presence of Culex pipiens biotype molestus in the Netherlands, and of hybrid biotype pipiens and molestus in northern Europe. J Vector Ecol. 2010;35:210-2.

6. Ciota AT, Chin PA, Kramer LD. The effect of hybridization of Culex pipiens complex mosquitoes on transmission of West Nile virus. Parasit Vectors. 2013;6:305.

7. Chevillon C, Eritja R, Pasteur N, Raymond M. Commensalism, adaptation and gene flow: mosquitoes of the Culex pipiens complex in different habitats. Genet Res. 1995;66:147-57.

8. Byrne K, Nichols RA. Culex pipiens in London underground tunnels: differentiation between surface and subterranean populations. Heredity. 1999;82:7-15.

9. Vinogradova EB. Culex pipiens pipiens mosquitoes: taxonomy, distribution, ecology, physiology, genetics, applied importance and control. Sofia: Pensoft Publishers; 2000.

10. Huang S, Molaei G, Andreadis TG. Genetic insights into the population structure of Culex pipiens (Diptera:Culicidae) in the northeastern United States by using microsatellite analysis. Am J Trop Med Hyg. 2008;79(4):518-27.

11. Weitzel T, Collado A, Jöst A, Pietsch K, Storch V, Becker N. Genetic differentiation of populations within the Culex pipiens complex and phylogeny of related species. J Am Mosq Control Assoc. 2009;25(1):6-17.

12. Farajollahi A, Fonseca DM, Kramer LD, Marm KA. "Bird biting" mosquitoes and human disease: a review of the role of Culex pipiens complex mosquitoes in epidemiology. Infect Genet Evol. 2011;11(7):1577-85.

13. Ferreira CAC, de Pinho Mixão V, Lourenço MT, Novo M, Palmeiro Calado MM, Pires Gonçalves LA, Duarte Belo SM, Gouveia de Almeida AP. First molecular identification of mosquito vectors of Dirofilaria immitis in continental Portugal. Parasit Vectors. 2015;8:139. 
14. Zittra C, Kocziha Z, Pinnyei S, Harl J, Kieser K, Laciny A, Eigner B, Silbermayr K, Duscher GG, Fok E, Fuehrer H-P. Screening blood-fed mosquitoes for the diagnosis of filarioid helminths and avian malaria. Parasit Vectors. 2015;8:16.

15. Fonseca DM, Keyghobadi N, Malcolm CA, Mehmet C, Schaffner F, Mogi M, Fleischer RC, Wilkerson RC. Emerging vectors in the Culex pipiens complex. Science. 2004;303(5663):1535-8.

16. Roiz D, Vazquez A, Rosà R, Muñoz J, Arnoldi D, Rosso F, Figuerola J, Tenorio A, Rizzoli Al. Blood meal analysis, flavivirus screening, and influence of meteorological variables on the dynamics of potential mosquito vectors of West Nile virus in northern Italy. J Vector Ecol. 2012;37(1):20-8.

17. Lebl K, Zittra C, Silbermayr K, Obwaller H, Berer D, Brugger K, Walter M Pinior B, Fuehrer H, Rubel F. Mosquitoes (Diptera: Culicidae) and their relevance as disease vectors in the city of Vienna, Austria. Parasitol Res. 2015;114:707-13.

18. Rizzoli A, Bolzoni L, Chadwick EA, Capelli G, Montarsi F, Grisenti M, de la Puente JM, Muñoz J, Figuerola J, Soriguer R, Anfora G, Di Luca M, Rosà R. Understanding West Nile virus ecology in Europe: Culex pipiens host feeding preference in a hotspot of virus emergence. Parasit Vectors. 2015:8:213.

19. Fros JJ, Vogels CB, Gaibani P, Sambri V, Martina BE, Koenraadt CJ, van Rij RP, Vlak JM, Takken W, Pijlman GP. Comparative Usutu and West Nile virus transmission potential by local Culex pipiens mosquitoes in north-western Europe. One Health. 2015;1:31-6.

20. Skogh M, Espmark $\AA$. Ockelbo disease: epidemic arthritis-exanthema syndrome in Sweden caused by Sindbis-virus like agent. Lancet. 1982; 319(8275):759-96.

21. Lvov DK, Skvortsova TM, Berezina LK, Gromashevsky VL, Yakovlev BI, Gushchin BV, Aristova VA, Sidorova GA, Gushchina EL, Klimenko SM. Isolation of the Karelian fever agent from Aedes communis mosquitoes. Lancet. 1984;324(8399):399-400.

22. Lundström JO, Turell MJ, Niklasson B. Effect of environmental temperature on the vector competence of Culex pipiens and Cx. torrentium for Ockelbo virus. Am J Trop Med Hyg. 1990;43(5):534-42.

23. Kurkela S, Rätti O, Huhtamo E, Uzcátegui NY, Nuorti JP, Laakkonen J, Mann $T$, Helle $P$, Vaheri $P$, Vapalahti $O$. Sindbis virus infection in resident birds, migratory birds, and humans, Finland. Emerg Infect Dis. 2008;14(1):41-7.

24. Jöst H, Bialonski A, Storch V, Günther S, Becker N, Schmidt-Chanasit J. Isolation and phylogenetic analysis of Sinbis viruses from mosquitoes in Germany. J Clin Microbiol. 2010;48:1900-3.

25. Hesson JC, Rettich F, Merdić E, Vignjevic G, Östmann Ö, Schäfer M, Schaffner F, Foussadier R, Besnard G, Medlock J, Scholte E-J, Lundström JO. The arbovirus vector Culex torrentium is more prevalent than Culex pipiens in northern and central Europe. Med Vet Entomol. 2014;28:179-86.

26. Nelms BM, Kothera L, Thiemann T, Macedo PA, Savage HM, Reisen WK. Phenotypic variation among Culex pipiens Complex (Diptera: Culicidae) populations from the Sacramento Valley, California: horizontal and vertical transmission of West Nile virus, diapause potential, autogeny, and host selection. Am J Trop Med Hyg. 2013;89(6):1168-78.

27. Samuel MD, Hobbelen PH, DeCastro F, Ahumada JA, LaPointe DA, Atkinson $C T$, Woodworth BL, Hart PJ, Duffy DC. The dynamics, transmission, and population impacts of avian malaria in native Hawaiian birds: a modeling approach. Ecol Appl. 2011;21(8):2960-73.

28. Werblow A, Bolius S, Dorresteijn AWC, Melaun C, Klimpel S. Diversity of Culex torrentium Martini, 1925 - a potential vector of arboviruses and filarial in Europe. Parasitol Res. 2013;112:2495-501.

29. Dahl C. Taxonomic studies on Culex pipiens and C. torrentium. In: Service MW, ed. Biosystematics of haematophagous insects. Systematics Association Special Volume 37. Oxford: Clarendon Press; 1988. p. 149-75.

30. Weitzel T, Jawień P, Rydzanicz K, Lonc E, Becker N. Culex pipiens s.l. and Culex torrentium (Culicidae) in Wrocław area (Poland): occurrence and breeding site preferences of mosquito vectors. Parasitol Res. 2015;114:289-95.

31. Becker N, Pedrić D, Zgomba M, Boase C, Madon M, Dahl C, Kaiser A. Mosquitoes and their control. Berlin: Springer; 2010.

32. Vinogradova EB, Shaikevich. A study of the distribution of the Culex pipiens complex (Insecta: Diptera: Culicidae) mosquitoes in the European part of Russia by molecular methods of identification. Comp Cytogenet. 2007;1:129-38.

33. Danabalan R, Ponsonby DJ, Linton Y-M. A critical assessment of available molecular identification tools for determining the status of Culex pipiens s.l. in the United Kingdom. J Am Mosq Control Assoc. 2012;28(4):68-74.

34. Smith JL, Fonseca DM. Rapid assays for identification of members of the Culex (Culex) pipiens complex, their hybrids, and other sibling species (Diptera: Culicidae). Am J Trop Med Hyg. 2004;70:339-45.
35. Sokal RR, Rholf FJ. Biometry: the principles and practice of statistics in biological research. 3rd ed. New York: Freeman \& Co.; 1995. p. 887.

36. European Environment Agency. CORINE Land Cover (CLC) 2006, Version 17. Copenhagen K; 2013. http://www.eea.europa.eu/data-and-maps/data/clc2006-vector-data-version-3. Accessed 6 Feb 2016.

37. Zittra C, Waringer J. Species inventory, ecology, and seasonal distribution patterns of Culicidae (Insecta: Diptera) in the National Park Donau-Auen (Lower Austria). Aquat Insects. 2014;36(1):63-77.

38. Roiz D, Ruiz S, Soriguer R, Figuerola J. Landscape effects on the presence, abundance and diversity of mosquitoes in Mediterranean wetlands. PLOS One. 2015;10(6):e0128112. doi:10.1371/journal.pone.0128112.

39. Oksanen J, Blanchet FG, Kindt R, Legendre P, Minchin PR, O'Hara RB, Simpson GL, Solymos P, Stevens MHH, Wagner H. Vegan: Community Ecology Package. R package version 2.2-1. 2015. http://CRAN.R-project.org/ package=vegan. Accessed 6 Feb 2016.

40. Mohrig W. Die Culiciden Deutschlands. Untersuchungen zur Taxonomie, Biologie und Ökologie der einheimischen Stechmücken. Parasitologische Schriftenreihe. 1969;18:1-261

41. Weitzel T, Braun K, Collado A, Jöst A, Becker N. Distribution and frequency of Culex pipiens and Culex torrentium (Culicidae) in Europe and diagnostic allozyme markers. Eur Mosq Bull. 2011;29:22-37.

42. Küpper S, Schulze S, Maier WA, Kampen H. Beitrag zum Vorkommen und zur Verbreitung von Stechmücken (Diptera: Culicidae) in Nordrheinwestfalen mit besonderer Berücksichtigung des Großraums Bonn. Mitteilungen der Deutschen Gesellschaft für Allgemeine und Angewandte Entomologie. 2006;15:337-44.

43. Jupp PG. Culex (Culex) pipiens and Culex (CX.) torrentium (Diptera: Culicidae) in England: Notes on their Taxonomy and Biology. Mosq Syst. 1979;11(2):121-6.

44. Gillies MT, Grubbins SJ. Culex (Culex) torrentium Martini and Cx. pipiens (L.) in a Southern English County, 1974-1975. Mosq Syst. 1982;14:127-30.

45. von Struppe T. Biologie und Ökologie von Culex torrentium Martini unter besonderer Berücksichtigung seiner Beziehungen im menschlichen Siedlungsbereich. Angew Zool. 1989;76(3):257-86.

46. Lühken R, Steinke S, Leggewie M, Tannich E, Krüger A, Becker S, Kiel E. Physico-chemical characteristics of Culex pipiens sensu lato and Culex torrentium (Diptera: Culicidae) breeding sites in Germany. J Med Entomol. 2015;52:932-6.

47. Snow KR, Medlock JM. The mosquitoes of Epping forest, Essex, UK. Eur Mosq Bull. 2008;26:9-17.

48. Amraoui F, Tijane M, Sarih M, Failloux A-B. Molecular evidence of Culex pipiens form molestus and hybrids pipiens/molestus in Morocco, North Africa. Parasit Vectors. 2012;5(1):83.

49. Gomes B, Sousa CA, Novo MT, Freitas FB, Alves R, Côrte-Real AR, Salgueiro P, Donnelly MJ, Almeida AP, Pinto J. Asymmetric introgression between sympatric molestus and pipiens forms of Culex pipiens (Diptera: Culicidae) in the Comporta region, Portugal. BMC Evol Biol. 2009:9:262.

50. Kiarie-Makara MW, Ngumbi PM, Dong-Kyu Lee. Effects of temperature on the growth and development of Culex pipiens complex mosquitoes (Diptera: Culicidae). IOSR-JPBS. 2015;10(6):01-10.

51. Harbach RE, Harrison BA, Gad AM. Culex (Culex) molestus Forskal (Diptera: Culicidae): neotype designation, description, variation, and taxonomic status. Proc Entomol Soc. 1984:86(3):521-42.

52. Kent RJ, Harrington LC, Norris DE. Genetic differences between Culex pipiens f. molestus and Culex pipiens pipiens (Diptera: Culicidae) in New York. J Med Entomol. 2007;44(1):50-9.

53. Hesson JC, Östman Ö, Schäfer M, Lundström JO. Geographic distribution and relative abundance of the sibling vector species Culex torrentium and Culex pipiens in Sweden. Vector Borne Zoonotic Dis. 2011;11:1383-9.

54. Beck M, Galm M, Weitzel T, Fohlmeister V, Kaiser A, Arnold A, Becker N. Preliminary studies in the mosquito fauna of Luxembourg. Eur Mosq Bull. 2003;14:21-4.

55. Pezzin A, Sy V, Puggioli A, Veronesi R, Carrieri M, Maccagnani B, Bellini R. Comparative study on the effectiveness of different mosquito traps in arbovirus surveillance with a focus on WNV detection. Acta Trop. 2016;153:93-100.

56. Gillies MT. The role of carbon dioxide in host-finding by mosquitoes (Diptera: Culicidae): a review. Bull Entomol Res. 1980;70(4):525-32.

57. Takken W. The role of olfaction in host-seeking of mosquitoes: a review. Int J Trop Insect Sci. 1991;12:287-95.

58. Dekker T, Geier M, Cardé RT. Carbon dioxide instantly sensitizes female yellow fever mosquitoes to human skin odours. J Exp Biol. 2005;208(15):2963-72. 
59. Hagelin JC, Jones IL. Bird odors and other chemical substances: a defense mechanism or overlooked mode of intraspecific communication? Auk. 2007;124(3):741-61.

60. Whittaker DJ, Soini HA, Atwell JW, Hollars C, Novotny MV, Ketterson ED. Songbird chemosignals: volatile compounds in preen gland secretions vary among individuals, sexes, and populations. Behav Ecol. 2010;21(3):608-14.

61. Brunetti AE, Hermida GN, lurman MG, Faivovich J. Odorous secretions in anurans: morphological and functional assessment of serous glands as a source of volatile compounds in the skin of the treefrog Hypsiboas pulchellus (Amphibia: Anura: Hylidae). J Anat. 2015. doi:10.1111/joa.12413.

62. Martin $\mathrm{SB}$, Jaeger RG, Prosen ED. Territorial red-backed salamanders can detect volatile pheromones from intruders. Herpetologica. 2005;61 (1):29-35.

Submit your next manuscript to BioMed Central and we will help you at every step:

- We accept pre-submission inquiries

- Our selector tool helps you to find the most relevant journal

- We provide round the clock customer support

- Convenient online submission

- Thorough peer review

- Inclusion in PubMed and all major indexing services

- Maximum visibility for your research

Submit your manuscript at www.biomedcentral.com/submit
Biomed Central 